\title{
Effect of oxidant concentration, exposure time, and seed particles on secondary organic aerosol chemical composition and yield
}

\author{
A. T. Lambe ${ }^{1,2}$, P. S. Chhabra ${ }^{2, *}$, T. B. Onasch ${ }^{1,2}$, W. H. Brune ${ }^{3}$, J. F. Hunter ${ }^{4}$, J. H. Kroll ${ }^{4}$, M. J. Cummings ${ }^{1}$, \\ J. F. Brogan ${ }^{1}$, Y. Parmar ${ }^{1}$, D. R. Worsnop ${ }^{2}$, C. E. Kolb ${ }^{2}$, and P. Davidovits ${ }^{1}$ \\ ${ }^{1}$ Chemistry Department, Boston College, Chestnut Hill, MA, USA \\ ${ }^{2}$ Aerodyne Research Inc., Billerica, MA, USA \\ ${ }^{3}$ Department of Meteorology and Atmospheric Sciences, Pennsylvania State University, State College, PA, USA \\ ${ }^{4}$ Department of Civil and Environmental Engineering, Massachusetts Institute of Technology, Cambridge, MA, USA \\ *now at: Department of Chemical Engineering, University of Texas, Austin, Texas, USA
}

Correspondence to: A. T. Lambe (lambe@aerodyne.com)

Received: 20 October 2014 - Published in Atmos. Chem. Phys. Discuss.: 2 December 2014

Revised: 13 February 2015 - Accepted: 27 February 2015 - Published: 18 March 2015

\begin{abstract}
We performed a systematic intercomparison study of the chemistry and yields of secondary organic aerosol (SOA) generated from OH oxidation of a common set of gasphase precursors in a Potential Aerosol Mass (PAM) continuous flow reactor and several environmental chambers. In the flow reactor, SOA precursors were oxidized using $\mathrm{OH}$ concentrations ranging from $2.0 \times 10^{8}$ to $2.2 \times 10^{10} \mathrm{molec} \mathrm{cm}^{-3}$ over exposure times of $100 \mathrm{~s}$. In the environmental chambers, precursors were oxidized using $\mathrm{OH}$ concentrations ranging from $2 \times 10^{6}$ to $2 \times 10^{7}$ molec $\mathrm{cm}^{-3}$ over exposure times of several hours. The $\mathrm{OH}$ concentration in the chamber experiments is close to that found in the atmosphere, but the integrated $\mathrm{OH}$ exposure in the flow reactor can simulate atmospheric exposure times of multiple days compared to chamber exposure times of only a day or so. In most cases, for a specific SOA type the most-oxidized chamber SOA and the least-oxidized flow reactor SOA have similar mass spectra, oxygen-to-carbon and hydrogen-to-carbon ratios, and carbon oxidation states at integrated $\mathrm{OH}$ exposures between approximately $1 \times 10^{11}$ and $2 \times 10^{11}$ molec $\mathrm{cm}^{-3} \mathrm{~s}$, or about $1-2$ days of equivalent atmospheric oxidation. This observation suggests that in the range of available $\mathrm{OH}$ exposure overlap for the flow reactor and chambers, SOA elemental composition as measured by an aerosol mass spectrometer is similar whether the precursor is exposed to low $\mathrm{OH}$ concentrations over long exposure times or high $\mathrm{OH}$ concentrations over short exposure times. This similarity in turn suggests that both in the flow reactor and in chambers, SOA chemi-
\end{abstract}

cal composition at low $\mathrm{OH}$ exposure is governed primarily by gas-phase $\mathrm{OH}$ oxidation of the precursors rather than heterogeneous oxidation of the condensed particles. In general, SOA yields measured in the flow reactor are lower than measured in chambers for the range of equivalent $\mathrm{OH}$ exposures that can be measured in both the flow reactor and chambers. The influence of sulfate seed particles on isoprene SOA yield measurements was examined in the flow reactor. The studies show that seed particles increase the yield of SOA produced in flow reactors by a factor of 3 to 5 and may also account in part for higher SOA yields obtained in the chambers, where seed particles are routinely used.

\section{Introduction}

Laboratory and field studies over the last decade have shown that organic components of atmospheric particles constitute 20 to $50 \%$ of the fine particle mass (PM) in the continental mid-latitudes, though the organic content can be higher (up to $90 \%$ ) in tropical forested regions (Kanakidou et al., 2005). On a global scale, 50-90\% of submicron organic PM is composed of oxygenated organic aerosol (Zhang et al., 2005) that is typically associated with secondary organic aerosol (SOA) formed by condensation of oxidized gasphase species (Jimenez et al., 2009). Field studies indicate that SOA particles may influence cloud formation (Levin et al., 2014; Mei et al., 2013; Moore et al., 2012; Sihto et al., 
2011) and may be optically active in the UV/visible region of the electromagnetic spectrum (Zhang et al., 2011). These studies have also revealed the complexity of organic aerosol compositions and their chemical evolution via oxidative aging. The atmospheric lifetime of ambient SOA ranges from hours to weeks, providing a wide range of atmospheric exposures to a variety of oxidant species. Measured ambient SOA chemical compositions range from hydrocarbon-like organic aerosol, such as observed directly downwind of the Deepwater Horizon oil site during the 2010 Gulf oil spill (Bahreini et al., 2012; De Gouw et al., 2011), to highly oxygenated OA, such as background SOA observed worldwide (Zhang et al., 2007). Much of this complexity is due to the thousands of organic compounds found in atmospheric particulate matter, specifically low volatility, highly functionalized species (Hallquist et al., 2009).

Laboratory experiments conducted in environmental chambers have been essential in providing SOA physical and chemical properties as well as yield data for predicting the rate of atmospheric SOA formation due to oxidation of biogenic and anthropogenic volatile organic compounds (VOCs) (Spracklen et al., 2011). Substantial progress has been made in understanding reaction mechanisms and the factors that influence SOA yields and composition. For example, SOA yields appear to have a complex dependence on VOC : $\mathrm{NO}_{\mathrm{x}}$ ratio (Loza et al., 2014; Ng et al., 2007), precursor concentration/volatility (Presto and Donahue, 2006), and oxidant exposure (Lambe et al., 2012). Modeling observed atmospheric SOA levels therefore remains a challenge (Shrivastava et al., 2011; Bergström et al., 2012; Jo et al., 2013; Li et al., 2013) because of the large number of modeling parameters and associated sensitivities that are required to capture mechanistic details of SOA formation (Chen et al., 2013; Fountoukis et al., 2014).

Oxidant exposure is the integral of the oxidant species concentration and the sample residence time. Relatively low oxidant exposures are a major limitation of current environmental chamber techniques, which operate at $\mathrm{OH}$ concentrations ranging from approximately $10^{6}$ to $10^{7} \mathrm{molec}^{-3}$ that are equal to or slightly more than daytime atmospheric $\mathrm{OH}$ concentrations. Losses of oxidized vapors (Ehn et al., 2014; Zhang et al., 2014) and/or particles to the chamber walls, as well as chamber deflation, generally limit chamber experiments to residence times of several hours. This combination of low $\mathrm{OH}$ concentrations and residence time limits environmental chambers to simulating atmospheric aerosol particle lifetimes only up to 1 or 2 days, including the characterization of SOA yields. This limitation prevents the formation and the study of highly oxygenated SOA that is characteristic of aged atmospheric organic aerosol PM (Ng et al., 2010).

Recently, aerosol flow reactors have been developed to study SOA formation and evolution equivalent to multiple days of atmospheric $\mathrm{OH}$ exposure. In these reactors $\mathrm{OH}$ concentrations are typically $\sim 10^{9}$ molec $\mathrm{cm}^{-3}$ or greater, with reactor residence times of seconds to minutes (Kang et al.,
2007; Hall IV et al., 2013; Keller and Burtscher, 2012; Lambe et al., 2011a; Slowik et al., 2012). With this range of $\mathrm{OH}$ concentrations and exposure times, flow reactors can simulate the full range of ambient levels of oxidation, measuring changes in SOA composition and yields over a wide range of equivalent atmospheric oxidation. Furthermore, because of the short flow reactor residence times, experimental runs can be conducted on the scale of minutes rather than hours.

While flow reactors appropriately simulate the full range of integrated atmospheric oxidant exposures, in view of their short residence times and high oxidant concentrations it must be established how well the atmospheric aerosol chemistry is simulated (Renbaum and Smith, 2011). A growing set of studies indicates that flow reactor-generated SOA particles have compositions similar to ambient SOA, suggesting that the dominant oxidation reaction pathways in flow reactors are similar to those in ambient conditions (Bahreini et al., 2012; Lambe et al., 2012, 2011b; Kang et al., 2011; Massoli et al., 2010; Ortega et al., 2013; Slowik et al., 2012; Tkacik et al., 2014; Wang et al., 2012; Wong et al., 2011). Other studies have used a combination of aerosol flow reactors and environmental chambers to characterize heterogeneous uptake of organics on seed particles (Jang et. al., 2003), SOA formation potential (Kang et al., 2007; Bernard et al., 2012), and evolution of functional groups in SOA with aging (Ofner et al., 2010); in general, similar results are obtained in reactors and chambers. However, these comparisons need to be extended over a wider range of reactants and experimental conditions than are currently available.

Here we describe systematic intercomparison studies of SOA chemistry and yields generated from a common set of precursors in a Potential Aerosol Mass (PAM) flow reactor (Lambe et al., 2011a) and four environmental chambers. SOA precursors studied are gas-phase alkane, biogenic, and aromatic compounds. SOA chemical composition and yield were characterized as a function of $\mathrm{OH}$ exposure. Additionally, the effect of sulfate seed particles on isoprene SOA yields was studied. Due to the limited oxidative exposure provided by the environmental chambers, direct comparison between the two techniques is possible only over a narrow range. However, reasonable extrapolations extend the range of interest.

\section{Experimental}

This manuscript compares properties of SOA produced in the PAM reactor to SOA produced in environmental chambers operated at the four institutions: California Institute of Technology (Caltech), Massachusetts Institute of Technology (MIT), Paul Scherrer Institute (PSI), and Carnegie Mellon University (CMU). The PAM reactor is a horizontal $13.3 \mathrm{~L}$ glass cylindrical chamber, $46 \mathrm{~cm}$ long $\times 22 \mathrm{~cm}$ ID and is operated in continuous flow mode with an average resi- 
dence time of $100 \mathrm{~s}$. The relative humidity $(\mathrm{RH})$ in the reactor was controlled in the range of $30-40 \%$. The Caltech, MIT, PSI, and CMU Teflon chambers range from 7.5 to $28 \mathrm{~m}^{3}$ in volume and are operated in batch or semi-batch mode with experimental residence times ranging from 4 to $10 \mathrm{~h}$. The $\mathrm{RH}$ in the Caltech, MIT and CMU chamber experiments was less than $10 \%$, and the RH in the PSI chamber experiments was controlled in the range of 40-50\%. A summary of the methods used for $\mathrm{OH}$ radical generation, particle generation, and data analysis is provided below.

\subsection{OH radical generation}

In the flow reactor, $\mathrm{OH}$ radicals were produced in the $\mathrm{ab}$ sence of $\mathrm{NO}_{\mathrm{x}}$ via the reaction $\mathrm{O}\left({ }^{1} \mathrm{D}\right)+\mathrm{H}_{2} \mathrm{O} \rightarrow 2 \mathrm{OH}$, with $\mathrm{O}\left({ }^{1} \mathrm{D}\right)$ radicals produced from the reaction $\mathrm{O}_{3}+h v \rightarrow \mathrm{O}_{2}+$ $\mathrm{O}\left({ }^{1} \mathrm{D}\right) \cdot \mathrm{O}_{3}(15-30 \mathrm{ppm})$ was generated by $\mathrm{O}_{2}$ irradiation with a mercury lamp $(\lambda=185 \mathrm{~nm})$ outside the flow reactor. The $\mathrm{O}\left({ }^{1} \mathrm{D}\right)$ atoms were produced by UV photolysis of $\mathrm{O}_{3}$ inside the flow reactor using four mercury lamps which emit primarily at $\lambda=254 \mathrm{~nm}$. Additional photons are emitted at the following wavelengths with relative intensities of $1 \%$ or more of the UV intensity at $254 \mathrm{~nm}: 185 \mathrm{~nm}$ (1\%; Li et. al., 2015); $302 \mathrm{~nm}(1 \%) ; 313 \mathrm{~nm}(1 \%) ; 366 \mathrm{~nm}$ (1\%); $405 \mathrm{~nm} \mathrm{(1 \% );} 436 \mathrm{~nm}(10 \%) ; 546 \mathrm{~nm} \mathrm{(1 \% )} \mathrm{(BHK}$ Inc. product specifications). At the highest UV intensity that was used in the reactor, we calculate upper-bound $J_{\mathrm{UV}}=2 \times 10^{13}$ and $2 \times 10^{15} \mathrm{~cm}^{-2} \mathrm{~s}^{-1}$ at $\lambda=185$ and $254 \mathrm{~nm}$ from ozone and $\mathrm{OH}$ exposure measurements. Corresponding lower limit timescales for UV photolysis of several phenols, carboxylic acids, aldehydes, and ketones range from 12 to $50000 \mathrm{~s}$ for absorption cross sections ranging from approximately $4 \times 10^{-17}$ to $1 \times 10^{-20} \mathrm{~cm}^{3}$ molec ${ }^{-1} \mathrm{~s}^{-1}$ (https: //sites.google.com/site/pamwiki/ and references therein).

In offline calibrations, $\mathrm{OH}$ concentrations were varied by changing the UV light intensity through stepping the lamp voltages between 0 and $110 \mathrm{~V}$. $\mathrm{SO}_{2}$ was added to the carrier gas, typically at mixing ratios ranging from 30 to $60 \mathrm{ppbv}$, and was used as an $\mathrm{OH}$ tracer. Calibrations were conducted at the same $\mathrm{H}_{2} \mathrm{O}$ and $\mathrm{O}_{3}$ concentrations used in SOA experiments. At each lamp setting, $\mathrm{OH}$ exposures were quantified by measuring the steady-state $\mathrm{SO}_{2}$ mixing ratio and normalizing to the $\mathrm{SO}_{2}$ mixing ratio obtained with the lamps turned off. The corresponding $\mathrm{OH}$ exposure was quantified by normalizing the $\mathrm{SO}_{2}$ mixing ratio with the lamps on to the $\mathrm{SO}_{2}$ mixing ratio with the lamps off and applying the known $\mathrm{OH}+\mathrm{SO}_{2}$ rate constant (Davis et al., 1979), as shown in Eq. (1):

$\mathrm{OH}$ exposure $=-\frac{1}{k_{\mathrm{SO}_{2}}^{\mathrm{OH}}} \ln \left(\frac{\left[\mathrm{SO}_{2}\right]}{\left[\mathrm{SO}_{2}\right]_{i}}\right)$.

The concentrations ranged from approximately $2.0 \times 10^{8}$ to $2.2 \times 10^{10}$ molec $\mathrm{cm}^{-3}$. The corresponding $\mathrm{OH}$ exposures ranged from $2.0 \times 10^{10}$ to $2.2 \times 10^{12}$ molec cm $^{-3} \mathrm{~s}$ or ap- proximately 0.2 to 17 days of equivalent atmospheric exposure. Additional $\mathrm{SO}_{2}$ calibration measurements were conducted in the presence and absence of a subset of precursors (isoprene and JP-10) to investigate reductions in $\mathrm{OH}$ levels following addition of those precursors to the flow reactor at mixing ratios that were used in SOA experiments. No change in $\mathrm{SO}_{2}$ decay was observed upon addition of isoprene, but addition of JP-10 decreased $\mathrm{OH}$ levels by approximately 10 (highest $\mathrm{OH}$ exposure) to $50 \%$ (lowest $\mathrm{OH}$ exposure) (Lambe et al., 2012). Reductions in $\mathrm{OH}$ exposure following addition of other VOCs will be investigated in future work using the methods of Li et. al. (2015).

In the environmental chambers, $\mathrm{OH}$ radicals were generated by UV photolysis $(\lambda=350 \mathrm{~nm})$ of hydrogen peroxide $\left(\mathrm{H}_{2} \mathrm{O}_{2}\right)$ with no added $\mathrm{NO}_{\mathrm{x}}$ or by UV photolysis of nitrous acid (HONO) or methyl nitrite $\left(\mathrm{CH}_{3} \mathrm{ONO}\right)$ with $\mathrm{NO}_{\mathrm{x}}$. In the present studies, $\mathrm{OH}$ radicals generated in the Caltech chamber were formed from photolysis of $\mathrm{H}_{2} \mathrm{O}_{2}, \mathrm{HONO}$, or $\mathrm{CH}_{3} \mathrm{ONO}$, depending on the experiment, whereas $\mathrm{OH}$ radicals generated in the MIT, PSI, and CMU chambers were formed exclusively from HONO photolysis. Typical chamber $\mathrm{OH}$ concentrations were approximately $2 \times 10^{6}$ molec $\mathrm{cm}^{-3}$ $\left(\mathrm{H}_{2} \mathrm{O}_{2}\right)$ and $2 \times 10^{7}$ molec $\mathrm{cm}^{-3}$ (HONO) during the initial stage of chamber experiments. Corresponding $\mathrm{OH}$ exposures ranged from $5.4 \times 10^{10}$ to $4.0 \times 10^{11}$ molec cm $^{-3} \mathrm{~s}$ (Table 1), equivalent to approximately 0.4 to 3 days of atmospheric exposure at a typical $24 \mathrm{~h}$ average $\mathrm{OH}$ concentration of $1.5 \times 10^{6}$ molec cm $^{-3}$ (Mao et al., 2009).

\subsection{Particle generation}

The gas-phase SOA precursors used in these studies include two biogenic compounds (isoprene, $\alpha$ pinene), three aromatic compounds (toluene, $m$-xylene, naphthalene), and three alkanes $\left(n-\mathrm{C}_{10}\right.$, cyclodecane, tricyclo[5.2.1.0 $0^{2,6}$ ]decane, a jet fuel also known as JP-10). In the flow reactor, SOA was generated via gas-phase $\mathrm{OH}$ oxidation of precursors followed by homogeneous nucleation or by condensation onto sulfuric acid or ammonium sulfate seed particles. The sulfuric acid seed particles were generated by $\mathrm{OH}$ oxidation of $\mathrm{SO}_{2}$ together with the $\mathrm{SOA}$ precursor, and ammonium sulfate seed particles were generated by atomizing an ammonium sulfate solution. The particles were dried and introduced continuously into the flow reactor (without radioactive charge neutralization) along with the gas-phase SOA precursor. In environmental chambers, SOA was generated via gas-phase $\mathrm{OH}$ oxidation of precursors usually followed by condensation onto ammonium sulfate seed particles. For long residence time chamber experiments, wall condensation of precursor gas-phase species can be significant. Seed particles are used in chamber studies to reduce wall effects. In some of the flow reactor experiments seed particles were also used to study their effect on SOA yields. 
Table 1. Summary of PAM reactor and environmental chamber $\mathrm{OH}$ exposure conditions.

\begin{tabular}{|c|c|c|c|c|c|c|}
\hline Precursor & PAM & Caltech & MIT & PSI & $\mathrm{CMU}$ & Refs \\
\hline isoprene & $1.6 \times 10^{11}-1.0 \times 10^{12}$ & $9.5 \times 10^{10}$ & - & - & - & $1-3,8$ \\
\hline$\alpha$-pinene & $2.0 \times 10^{10}-2.2 \times 10^{12}$ & $5.4 \times 10^{10}-1.3 \times 10^{11}$ & - & $9.0 \times 10^{10}-4.0 \times 10^{11}$ & - & $1-4,7-8,10$ \\
\hline toluene & $1.6 \times 10^{11}-2.1 \times 10^{12}$ & $1.5 \times 10^{11}$ & - & - & - & $1-3,8$ \\
\hline$m$-xylene & $4.1 \times 10^{10}-2.1 \times 10^{12}$ & $7.7 \times 10^{10}-1.6 \times 10^{11}$ & - & - & - & $1-3,7-8$ \\
\hline naphthalene & $1.6 \times 10^{11}-2.1 \times 10^{12}$ & $2.3 \times 10^{11}$ & - & - & - & $2-3,8,10$ \\
\hline$n-\mathrm{C}_{10}$ & $1.6 \times 10^{11}-2.1 \times 10^{12}$ & - & $2.6 \times 10^{11}$ & - & - & $1,5,9$ \\
\hline cyclodecane & $1.6 \times 10^{11}-1.9 \times 10^{12}$ & - & $1.8 \times 10^{11}$ & - & $2.2 \times 10^{10}$ & $1,5-6$ \\
\hline JP-10 & $1.3 \times 10^{11}-2.0 \times 10^{12}$ & - & $3.3 \times 10^{11}-5.8 \times 10^{11}$ & - & - & $5,9-10$ \\
\hline
\end{tabular}

References: 1 this work; 2 Chhabra et al. (2010); 3 Chhabra et al. (2011); 4 Pfaffenberger et al. (2013); 5 Hunter et al. (2014); 6 Tkacik et al. (2012); 7 Lambe et al. (2011a); 8 Lambe et al. (2011b); 9 Lambe et al. (2012); 10 Lambe et al. (2013).

\subsection{Particle monitoring and analysis}

Particle number concentrations and size distributions were measured with a TSI scanning mobility particle sizer (SMPS). Aerosol mass spectra were measured with an Aerodyne time-of-flight aerosol mass spectrometers (ToF-AMS) (DeCarlo et al., 2006; Drewnick et al., 2005). Elemental analysis (Aiken et al., 2008) was performed on the AMS data to determine the bulk aerosol hydrogen-to-carbon $(\mathrm{H} / \mathrm{C})$ and oxygen-to-carbon $(\mathrm{O} / \mathrm{C})$ ratios along with the average aerosol carbon oxidation state $(\overline{\mathrm{OSc}})$ (Kroll et al., 2011). While AMS measurements provide basic information about SOA composition, additional supporting measurements such as Fourier transform infrared spectroscopy, nuclear magnetic resonance, gas chromatography mass spectrometry, and chemical ionization mass spectrometry are required to investigate SOA chemistry at the molecular level.

SOA yields were calculated from the ratio of aerosol mass formed to precursor gas reacted. The aerosol mass was calculated from the integrated particle volume and the effective particle density $\left(\rho=D_{\mathrm{va}} / D_{\mathrm{m}}\right)$, where $D_{\mathrm{va}}$ is the mean vacuum aerodynamic diameter obtained from the ToFAMS and $D_{\mathrm{m}}$ is the electric mobility diameter obtained from the SMPS. Flow reactor SOA yields were corrected using size-dependent bis(2-ethylhexyl) sebacate wall-loss measurements (Lambe et al., 2011a); the average magnitude of these corrections was $32 \%( \pm 15 \%)$ and represents an upper limit as it combines losses into and through the reactor. Caltech chamber yields were corrected for particle wall losses using size-dependent first-order loss coefficients determined from ammonium sulfate wall-loss measurements (Keywood et al., 2004). The magnitude of these particle wall loss corrections typically ranged from 10 to $30 \%$.

MIT chamber experiments were corrected for particle wall losses using the AMS organic-to-sulfate ratio to generate an upper limit and SMPS measurements of particle loss to generate a lower limit for aerosol yield (Hildebrandt et al., 2009). In the MIT chamber, these corrections were between a factor of 1.5 and 3.0 at the highest yields and $\mathrm{OH}$ exposures. Although the residence time in the flow reactor is much shorter than in the chambers, the surface-to-volume ratio in the PAM reactor is much greater. As a result, particle losses are comparable in the two systems. Flow reactor SOA yields were also corrected for UV lamp-induced temperature increases by applying yield corrections of -0.02 per $\mathrm{K}$ of temperature rise (Qi et al., 2010; Stanier et al., 2007) relative to room temperature $(\sim 293 \mathrm{~K})$. These temperature corrections ranged from 0 to $28 \%$ (mean correction $\pm 1 \sigma=7 \pm 7 \%$ ). In the flow reactor, a known amount of precursor gas was introduced and the mass of reacted precursor gas was estimated from the $\mathrm{OH}$ exposure and known bimolecular rate constants (Atkinson, 1986). In environmental chamber studies, the mass of the remaining precursor gas was measured directly as a function of exposure time.

\section{Results and discussion}

\subsection{Sample mass spectra of flow reactor- and chamber-generated SOA}

Figure 1 shows representative ToF-AMS spectra of SOA generated in the PAM reactor and the Caltech chamber (Chhabra et al., 2010, 2011) from the $\mathrm{OH}$ oxidation of $\alpha$-pinene and naphthalene, used here as representative biogenic and anthropogenic precursors, respectively. The flow reactor spectra are obtained at an $\mathrm{OH}$ exposure of $1.6 \times 10^{11} \mathrm{molec} \mathrm{cm}^{-3} \mathrm{~s}$, or $\sim 1$ day of equivalent atmospheric oxidation. The chamber spectra represent the SOA composition at peak aerosol formation $\left(\sim 9 \times 10^{10} \mathrm{molec}^{-3} \mathrm{~s} \mathrm{OH}\right.$ exposure). In this range the $\mathrm{OH}$ exposure for the PAM reactor and chamber are approximately the same, allowing for direct comparison.

To quantify the similarity between mass spectra, we calculated the dot product between SOA mass spectra generated in the PAM flow reactor and the Caltech chamber (Murphy et. al., 2003; Marcolli et al., 2006). Using this approach, each mass spectral signal is normalized to the square root of the sum of the squares of all signals in the mass spectrum. Each spectrum is represented as a normalized vector $\mathrm{A}$ or $\mathrm{B}$, with dot product $\mathrm{A} \cdot \mathrm{B}=\sum_{i=1}^{n} a_{i} b_{i}$, where $a_{i}$ and $b_{i}$ are the normalized signals at each $\mathrm{m} / \mathrm{z}$ in the spectrum; $\mathrm{A} \cdot \mathrm{B}=0$ indicates 


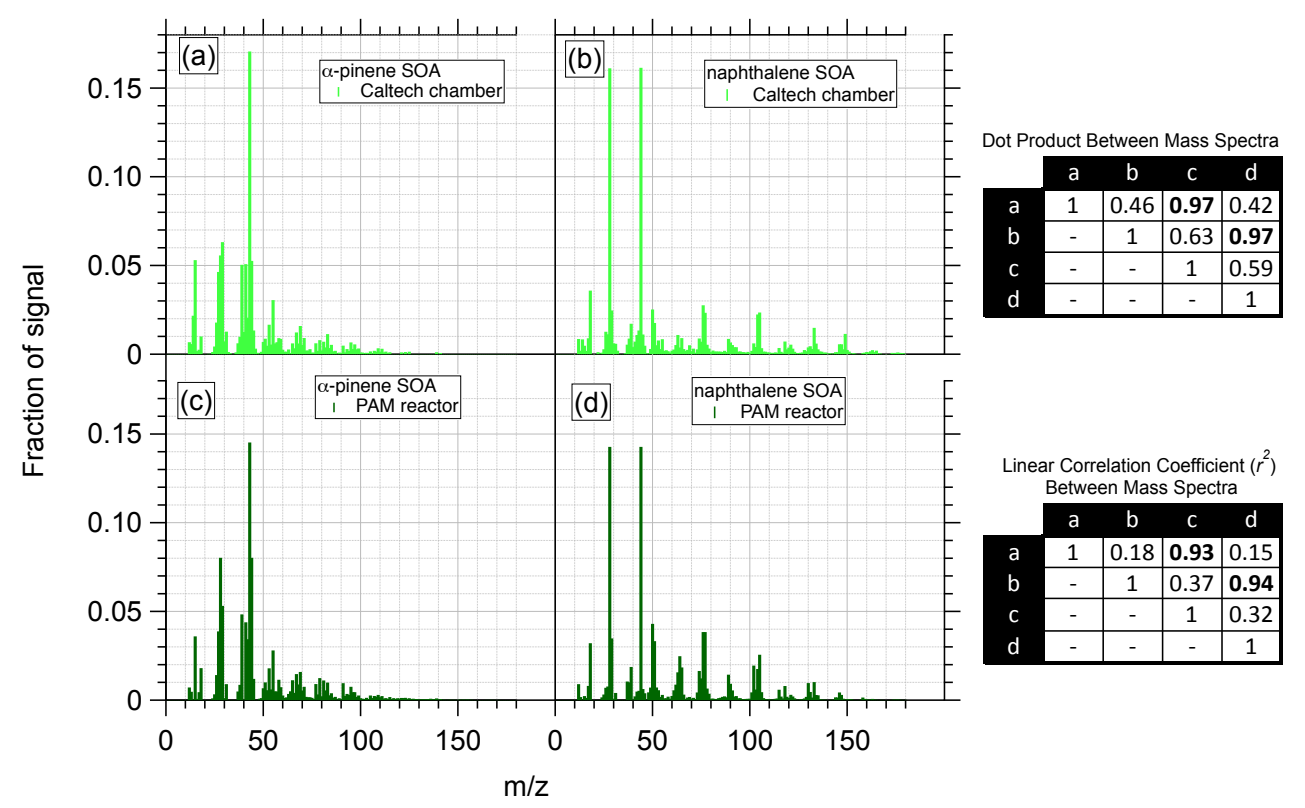

Figure 1. Aerodyne ToF-AMS spectra of SOA generated in the (a and b) Caltech environmental chamber and (c and d) PAM flow reactor from the $\mathrm{OH}$ oxidation of $\alpha$-pinene and naphthalene. Caltech chamber data obtained from Chhabra et al. (2011).

the spectra are orthogonal and $\mathrm{A} \cdot \mathrm{B}=1$ indicates the spectra are identical.

The top table inset in Fig. 1 shows the calculated dot products between each pair of mass spectra. The PAM flow reactor and the chamber produce particles with similar mass spectra, as indicated by dot products of 0.97 between spectra shown in Fig. 1a and c ( $\alpha$-pinene SOA) and Fig. 1b and $\mathrm{d}$ (naphthalene SOA), suggesting similar compositions. Features unique to $\alpha$-pinene and naphthalene SOA are observed in both flow reactor- and chamber-obtained spectra, with linear correlation coefficients of $r^{2}=0.93(\alpha$-pinene SOA) and $r^{2}=0.94$ (naphthalene SOA) as noted in the bottom table inset in Fig. 1. For example, $\alpha$-pinene SOA spectra are dominated by signals at $m / z=43\left(\mathrm{C}_{2} \mathrm{H}_{3} \mathrm{O}^{+}\right)$indicative of carbonyls and several ion clusters below $m / z<100$ containing signals that are indicative of cycloalkyl fragments such as $m / z=27,41$, and 55. However, AMS spectra of naphthalene SOA are dominated by $m / z=44\left(\mathrm{CO}_{2}^{+}\right)$, indicative of carboxylic acids, as well as signals that are indicative of aromatic compounds such as $m / z=50-51,65$, and 76-77. As is evident from Fig. 1, $\alpha$-pinene and naphthalene SOA mass spectra display pronounced differences, with dot products ranging from 0.42 to 0.63 and $r^{2}$ ranging from 0.18 to 0.37 between spectra shown in Fig. 1a and b, 1a and d, 1b and $\mathrm{c}$, and $1 \mathrm{c}$ and $\mathrm{d}$.

\section{2 $\mathrm{H} / \mathrm{C}, \mathrm{O} / \mathrm{C}$ ratios for flow reactor- and chamber-generated SOA}

$\mathrm{H} / \mathrm{C}$ and $\mathrm{O} / \mathrm{C}$ ratios obtained from mass spectra such as shown in Fig. 2 provide information about the nature of
SOA formation. Van Krevelen diagrams that show $\mathrm{H} / \mathrm{C}$ ratios as a function of $\mathrm{O} / \mathrm{C}$ ratios have been used to deduce oxidation reaction mechanisms for organic aerosols (Heald et al., 2010). Typically, with oxidative aging the $\mathrm{O} / \mathrm{C}$ ratio increases and $\mathrm{H} / \mathrm{C}$ ratio of SOA decreases as oxygencontaining functional groups are added to a carbon backbone. Here, we use Van Krevelen diagrams to compare the composition of SOA formed in the flow reactor and environmental chambers for the organic precursors studied. Direct comparisons are possible in the overlapping $\mathrm{OH}$ exposure region. Typically the lowest $\mathrm{OH}$ exposures attained in the flow reactor overlap (or nearly overlap) with the highest $\mathrm{OH}$ exposures reached in environmental chambers (Table 1).

Figure 2 shows Van Krevelen diagrams obtained from laboratory SOA produced from the oxidation of gas-phase biogenic, aromatic, and alkane precursors. To simplify presentation, the data are displayed in three panels. Figure 2a shows biogenic SOA generated from isoprene and $\alpha$-pinene, Fig. 2b shows SOA generated from aromatic compounds, and Fig. 2c shows SOA produced from alkanes. In most cases, for a specific SOA type the most-oxidized chamber SOA and the least-oxidized flow reactor SOA have similar Van Krevelen plots at integrated $\mathrm{OH}$ exposures between approximately $1 \times 10^{11}$ and $2 \times 10^{11}$ molec cm $^{-3} \mathrm{~s}$, or about $1-2$ days of equivalent atmospheric oxidation. This observation suggests that in the range of available $\mathrm{OH}$ exposure overlap for the flow reactor and chambers, SOA elemental composition is similar whether the precursor is exposed to low $\mathrm{OH}$ concentrations over long exposure times or high $\mathrm{OH}$ concentrations over short exposures times. The flow reactor studies were done without added $\mathrm{NO}_{\mathrm{x}}$, whereas some of the environmen- 


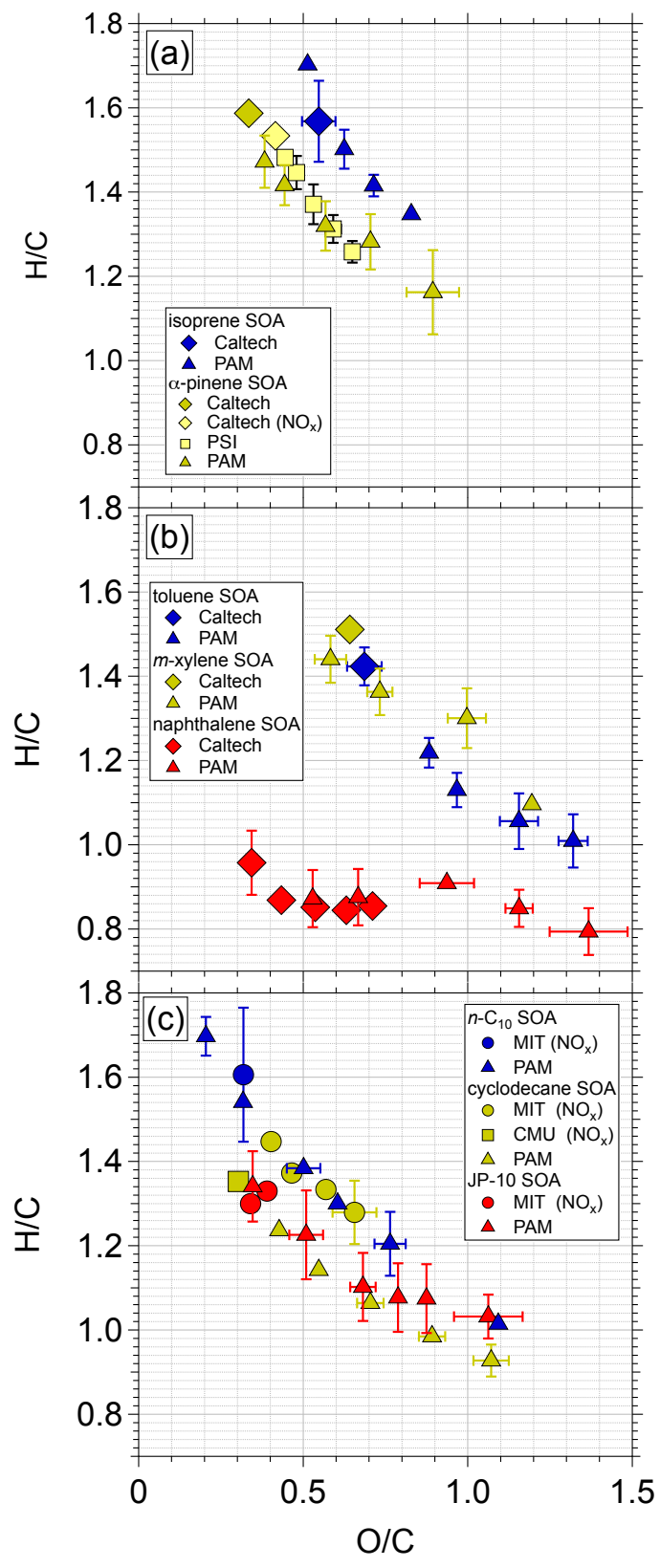

Figure 2. Van Krevelen diagrams showing $\mathrm{H} / \mathrm{C}$ ratio as a function of $\mathrm{O} / \mathrm{C}$ ratio for SOA generated in the PAM flow reactor and environmental chambers by $\mathrm{OH}$ oxidation of (a) biogenic, (b) aromatic, and (c) alkane precursors. Error bars indicate $\pm 1 \sigma$ uncertainty in binned $\mathrm{O} / \mathrm{C}$ and $\mathrm{H} / \mathrm{C}$ ratio measurements. Caltech, PSI, CMU, and MIT chamber data obtained from Chhabra et al. (2011), Pfaffenberger et al. (2013) (binned averages of $\mathrm{O} / \mathrm{C}$ and $\mathrm{H} / \mathrm{C}$ data from experiments 1-9), Tkacik et al. (2012), and Hunter et al. (2014), respectively.

tal chamber studies were conducted in the presence of $\mathrm{NO}_{\mathrm{x}}$. The similarity in compositional parameters shown in Fig. 2 (e.g., $\mathrm{H} / \mathrm{C}, \mathrm{O} / \mathrm{C}$ ) were independent of the $\mathrm{NO}_{\mathrm{x}}$ levels used in the environmental chambers in the region studied, as has

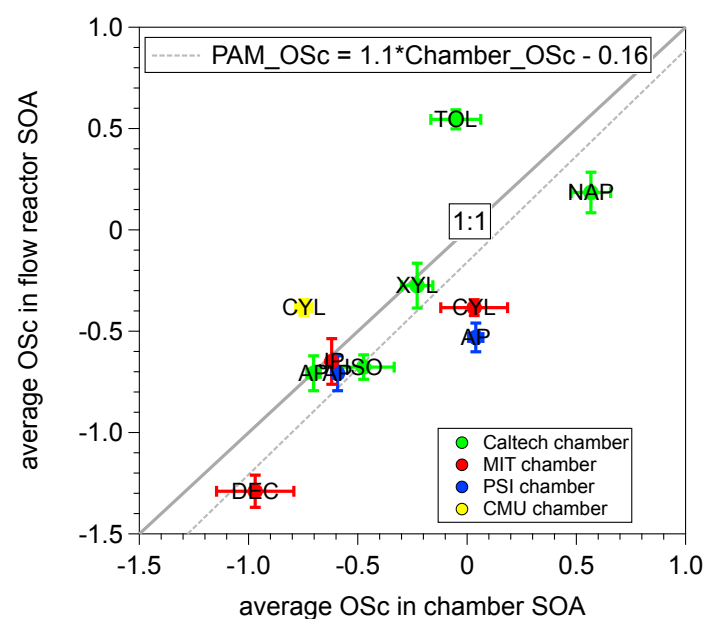

Figure 3. Average carbon oxidation state $(\overline{\mathrm{OSc}} ; \overline{\mathrm{OSc}}=2 \times \mathrm{O} / \mathrm{C}-$ $\mathrm{H} / \mathrm{C}$ ) of flow reactor- and environmental chamber-generated SOA. Error bars indicate $\pm 1 \sigma$ uncertainty in binned $\overline{\mathrm{OSc}}$ measurements. Markers indicate SOA precursor: TOL is toluene, NAP is naphthalene, XYL is $m$-xylene, CYL is cyclodecane, JP is JP-10, ISO is isoprene, AP is $\alpha$-pinene, and DEC $=n-\mathrm{C}_{10}$. Caltech, PSI, CMU, and MIT chamber data obtained from Chhabra et al. (2011), Pfaffenberger et al. (2013), Tkacik et al. (2012), and Hunter et al. (2014), respectively.

been observed in previous studies (Chhabra et al., 2011). The nitrogen-to-carbon $(\mathrm{N} / \mathrm{C})$ ratio ranged from 0.031 to 0.054 for SOA produced in the MIT chamber with added $\mathrm{NO}_{\mathrm{x}}$ (Hunter et al., 2014) but was not characterized for other measurements shown in Fig. 2.

\subsection{Carbon oxidation state for flow reactor- and chamber-generated SOA}

Recently, the average carbon oxidation state, defined as $\overline{\mathrm{OSc}}=2 \times \mathrm{O} / \mathrm{C}-\mathrm{H} / \mathrm{C}$, was proposed as a more accurate indicator of atmospheric oxidative aging processes than the $\mathrm{O} / \mathrm{C}$ ratio alone because this measure takes into account the level of saturation of the carbon atoms in the SOA (Canagaratna et al., 2015; Kroll et al., 2011). As will be demonstrated, $\overline{\mathrm{OSc}}$ of lightly oxidized SOA is strongly precursordependent. Figure 3 shows a scatter plot of $\overline{\mathrm{OSc}}$ for flow reactor and chamber SOA for the eight gas-phase precursors studied. Different colored symbols are used to represent each of the environmental chambers used in the intercomparison. For each data point obtained from environmental chamber measurements, we used data from the flow reactor obtained at the $\mathrm{OH}$ exposure that were closest in magnitude. A total linear least squares fit to the data presented in Fig. $3\left(\mathrm{PAM}_{\overline{\mathrm{OSc}}}=1.1 \cdot\right.$ Chamber $\left.\overline{\mathrm{OSc}}-0.16 ; r^{2}=0.54\right)$ indicates that there is no systematic $\overline{\mathrm{OSc}}$ difference observed across multiple SOA types produced in chambers and in flow reactors. For a specific SOA type, Fig. 3 shows that the chambers and flow reactor provide $\overline{\mathrm{OSc}}$ with absolute differences 


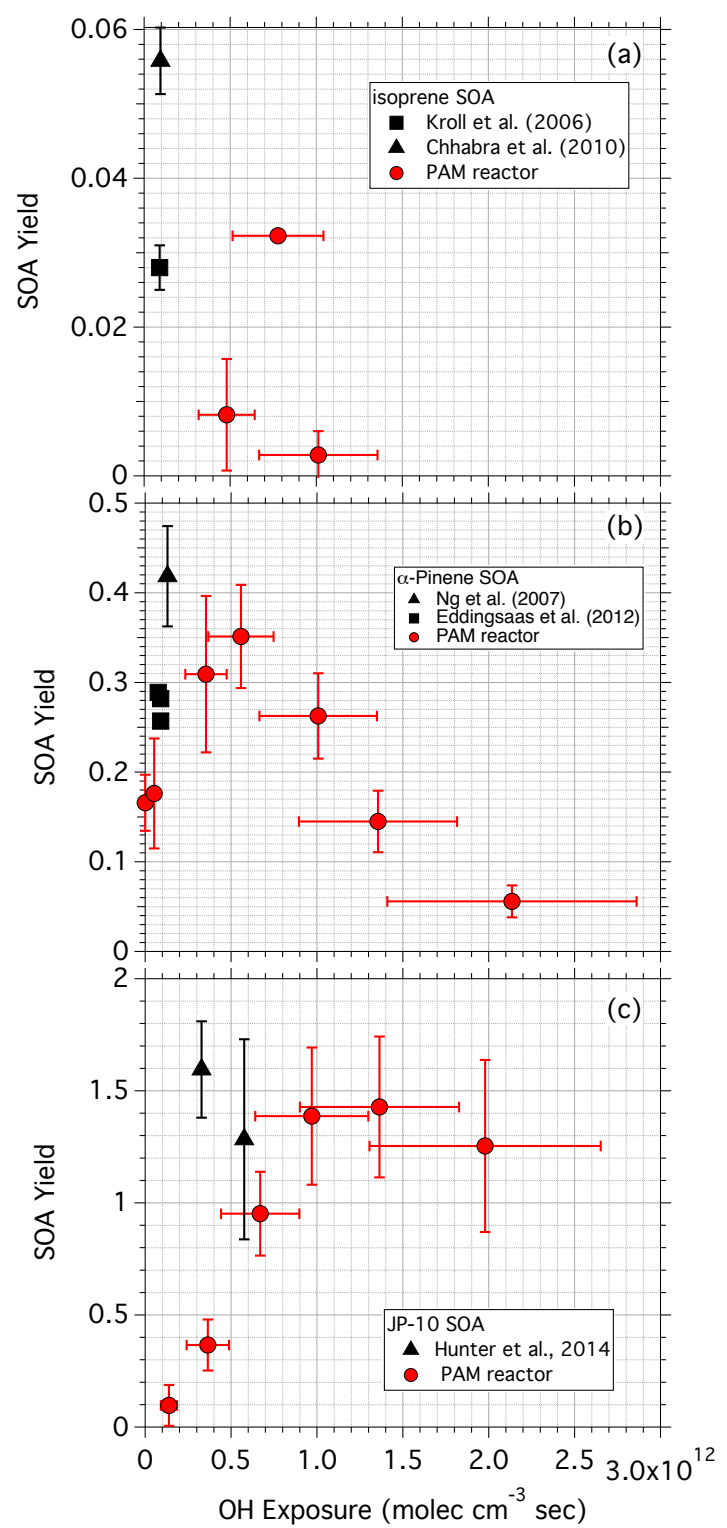

Figure 4. Yields of SOA produced from photooxidation of (a) isoprene, (b) $\alpha$-pinene, and (c) tetracyclo[5.2.1.0 2,6 decane (JP-10) in environmental chambers and PAM reactor as a function of $\mathrm{OH}$ exposure. The $\mathrm{OH}$ exposure in (c) is corrected for reductions in $\mathrm{OH}$ levels upon JP-10 addition (see Sect. 2.1). Error bars indicate $\pm 1 \sigma$ uncertainty in binned SOA yield measurements and $\pm 34 \%$ uncertainty in $\mathrm{OH}$ exposure values ( $\mathrm{Li}$ et. al., 2015). Black markers indicate data from (Kroll et al., 2006; Chhabra et al., 2010; Eddingsaas et al., 2012), and $\mathrm{Ng}$ et al. (2007) obtained in the Caltech chamber and data from Hunter et al. (2014) obtained in the MIT chamber.

ranging from 0.0040 to 0.60 (mean deviation $=0.10 \pm 0.34$ ) over the range of measured SOA composition for comparable $\mathrm{OH}$ exposures. The observed deviations between PAM and chamber $\overline{\mathrm{OSc}}$ are no larger than deviations between two chambers (e.g., $\alpha$-pinene SOA produced in Caltech and PSI

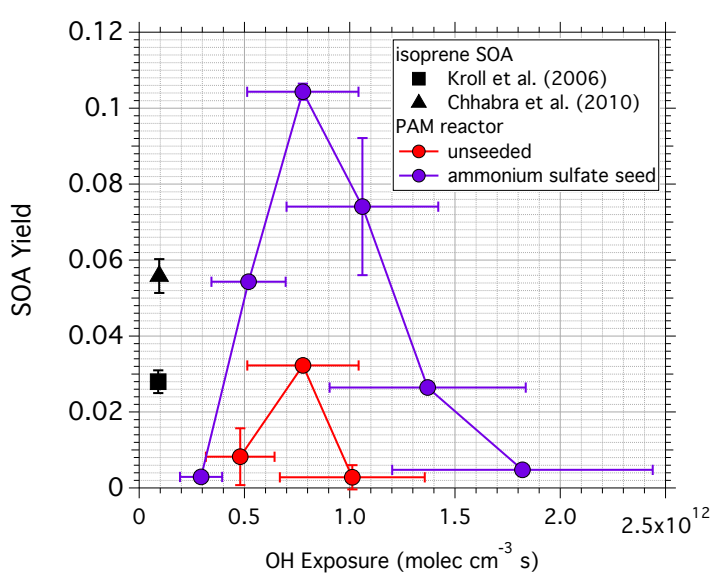

Figure 5. Yields of SOA produced from photooxidation of isoprene in the PAM reactor as a function of $\mathrm{OH}$ exposure in the presence of $20 \mathrm{\mu} \mathrm{m}^{-3}$ ammonium sulfate seed. Error bars indicate $\pm 1 \sigma$ uncertainty in binned SOA yield measurements and $\pm 34 \%$ uncertainty in $\mathrm{OH}$ exposure values ( $\mathrm{Li}$ et. al., 2015).

chambers and cyclodecane SOA produced in MIT and CMU chambers).

\subsection{SOA yields obtained in the flow reactor and environmental chambers}

Several factors can affect SOA yields, including precursor concentration (Kang et al., 2011; Pfaffenberger et al., 2013; Presto and Donahue, 2006), $\mathrm{NO}_{\mathrm{x}}$ (Presto et al., 2005; Ng et al., 2007), UV intensity/wavelength (Henry and Donahue, 2012), seed particle composition/loading (Ehn et al., 2014; Hamilton et al., 2011; Volkamer et al., 2009), and interactions between SOA and chamber walls (Hildebrandt et al., 2009; Matsunaga and Ziemann, 2010; Pierce et al., 2008; Zhang et al., 2014). For reference, the range of SOA precursor concentrations, $\mathrm{NO}_{\mathrm{x}}$ levels, and seed particle concentrations used in SOA yield studies is summarized in Table 2. Isolation of individual factors is beyond the scope of this intercomparison. Because mass spectra and elemental ratios of SOA are similar whether it is generated in an environmental chamber or in a flow reactor (Sect. 3.1), we suggest that the differences in precursor concentration and UV wavelength (e.g., $\lambda=350 \mathrm{~nm}$ vs. $\lambda=254 \mathrm{~nm}$ ) used in these studies have at most a minor effect on bulk composition.

Next we evaluate the influence of oxidant concentration and residence time on yields of SOA formed from common precursors in the PAM reactor and the Caltech and MIT environmental chambers. Figure 4 shows yields of SOA as a function of $\mathrm{OH}$ exposure for isoprene SOA (no added $\mathrm{NO}_{\mathrm{x}}$ ), $\alpha$-pinene SOA (no added $\mathrm{NO}_{\mathrm{x}}$ ), and tricyclo[5.2.1.0 $0^{2,6}$ ]decane (JP-10) SOA, respectively. These precursors provide the broadest range of available yield values for intercomparison. Oxidation of isoprene forms SOA with low yield (Chhabra et al., 2010; Kroll et al., 2006), 
Table 2. Experimental conditions for PAM reactor, Caltech chamber, and MIT chamber yield measurements shown in Figs. 5-7.

\begin{tabular}{lllllll}
\hline & $\begin{array}{l}\text { Seed concentration } \\
\left(\mu \mathrm{g} \mathrm{m}^{-3}\right)\end{array}$ & $\begin{array}{l}\text { Maximum }\left[\mathrm{NO}_{\mathrm{x}}\right] \\
\mathrm{added}(\mathrm{ppb})\end{array}$ & $\begin{array}{l}\text { [isoprene] } \\
(\mathrm{ppb})\end{array}$ & $\begin{array}{l}{[\alpha \text {-pinene] }} \\
(\mathrm{ppb})\end{array}$ & $\begin{array}{l}{[\mathrm{JP}-10]} \\
(\mathrm{ppb})\end{array}$ & Refs \\
\hline $\begin{array}{l}\text { Caltech chamber } \\
\text { MIT chamber }\end{array}$ & $0-29^{\mathrm{a}}$ & 0 & $49-91$ & $13.8-52.4$ & - & $1-3$ \\
PAM flow reactor & $0-100^{\mathrm{a}}$ & 475 & - & - & 42.9 & 4 \\
\hline
\end{tabular}

${ }^{\mathrm{a}}$ Ammonium sulfate seed; ${ }^{\mathrm{b}}$ sulfuric acid seed;

1 Chhabra et al. (2010); 2 Ng et al. (2007); 3 Eddingsaas et al. (2012); 4 Hunter et al. (2014); 5 this work; 6 Lambe et al. (2012);

7 Chen et al. (2013).

whereas $\alpha$-pinene forms SOA with moderate yields (Eddingsaas et al., 2012) and JP-10 forms SOA with mass yields greater than unity (Hunter et al., 2014; Lambe et al., 2012). Yields of alkane SOA do not display a systematic $\mathrm{NO}_{\mathrm{x}}$ dependence (Loza et al., 2014); thus, to first order we assume different $\mathrm{NO}_{\mathrm{x}}$ levels between the MIT chamber and PAM reactor do not influence our comparison of measured JP-10 SOA yields. The following features are evident in Fig. 4:

1. SOA yields at comparable $\mathrm{OH}$ exposures are lower in the flow reactor than in chambers, whereas the mass spectra, $\mathrm{O} / \mathrm{C}$, and $\mathrm{H} / \mathrm{C}$ of SOA generated in the chambers and flow reactor are similar (Figs. 1-3). Flow reactor SOA yields are also lower in the flow reactor than in chambers for the other precursors studied that are not shown in Fig. 4.

2. SOA yields in the flow reactor and chambers track each other; that is, the maximum yield of isoprene SOA is approximately 0.03 in the flow reactor and 0.06 in the Caltech chamber (Fig. 4a). Likewise, the maximum yield of JP-10 SOA is 1.4 in the flow reactor and 1.6 in the MIT chamber (Fig. 4c).

3. In the flow reactor, in all cases the SOA yield first increases as a function of $\mathrm{OH}$ exposure and then decreases. In some cases there is also evidence of a slight decrease in SOA yields at higher $\mathrm{OH}$ exposure in chambers (e.g., Fig. 4c).

One reason for the lower SOA yield in flow reactors may be the relative timescales for oxidation in the gas-phase vs. condensation onto pre-existing aerosols. The timescale for condensation of a gas-phase molecule onto pre-existing seed particles $\left(\tau_{\text {cond }}\right)$ can be calculated using Eq. (2) (Seinfeld and Pandis, 2006):

$\tau_{\text {cond }}=\frac{1}{\alpha A_{\mathrm{p}}} \sqrt{\frac{2 \pi M_{\mathrm{w}}}{k_{\mathrm{B}} T}}$

where $M_{\mathrm{w}}$ is the molecular weight of the condensing species, $\alpha$ is the mass accommodation coefficient, and $A_{\mathrm{p}}$ is the particle surface area. For example, over a representative range of particle surface area concentrations used in the flow reactor
(10 to $100 \mu \mathrm{m}^{2} \mathrm{~cm}^{-3}$ ), condensation timescales range from approximately 2000 to $20000 \mathrm{~s}$ assuming a mass accommodation coefficient of 0.1 as has been measured for $\alpha$-pinene ozonolysis SOA (Saleh et al., 2013) and an average SOA molecular weight of $150 \mathrm{~g} \mathrm{~mol}^{-1}$. A lower limit of $\tau_{\text {cond }}=$ 200 to $2000 \mathrm{~s}$ is calculated over the same range of $A_{\mathrm{p}}$ assuming $\alpha=1$. While our measurements do not constrain the mass accommodation coefficient, these timescales suggest that the residence time in the flow reactor ( $100 \mathrm{~s})$ may not be adequate to allow complete condensation of semivolatile organic gas-phase species into SOA, whereas residence times in environmental chamber experiments are typically $10000 \mathrm{~s}$ or longer. Another factor in causing the SOA yield difference may be due to the condensation conditions. All the chamber experiments displayed in this work were done in the presence of ammonium sulfate seed particles, whereas seed particles were not normally used in our flow reactor studies. The effect of seed particles on SOA yields in the flow reactor is examined further in Sect. 3.5.

The observation that the yields track each other is a further indication that the reactive chemistry in the two systems is similar. The decrease in SOA yield subsequent to increase as a function of $\mathrm{OH}$ exposure is possibly due to gas-phase species carbon-carbon bond breaking from continued oxidation or heterogeneous $\mathrm{OH}$ oxidation reactions at high $\mathrm{OH}$ exposure (Hunter et al., 2014; Lambe et al., 2012; Loza et al., 2012); this trend is most clearly evident in the flow reactor studies. These observations suggest that the first step in SOA formation is oxidation of gas-phase species leading to subsequent condensation. At low $\mathrm{OH}$ exposures equivalent to $1-$ 2 days, heterogeneous reactions do not appear to play a significant role in SOA chemistry (Cappa and Wilson, 2012; Chen et al., 2013).

\subsection{Effect of seed particles on SOA yields}

The chamber experiments discussed in Sects. 3.1-3.4 were performed in the presence of ammonium sulfate seeds to promote more rapid condensation of gas-phase species into SOA. We investigated in more detail the influence of sulfate seed particle loading and composition on SOA yields produced in the flow reactor. We hypothesize that a "seed effect" should be most pronounced for SOA types with low yields 


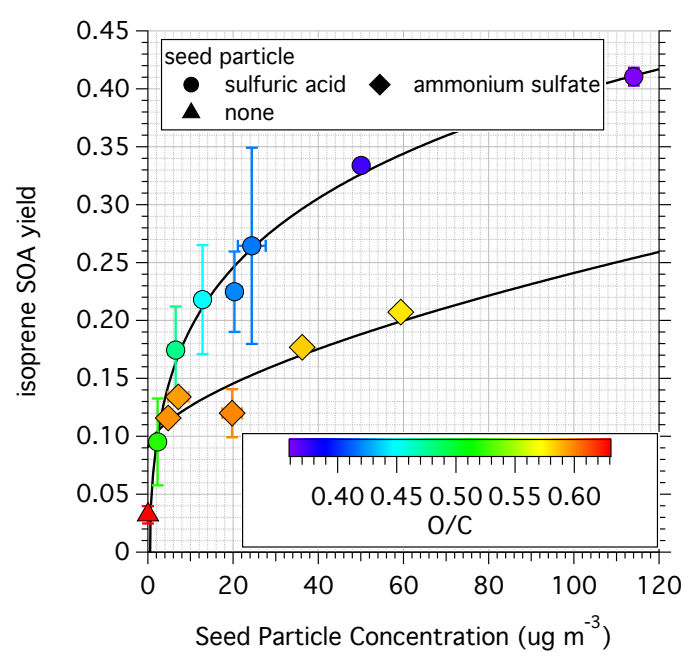

Figure 6. Yields of isoprene SOA produced in the PAM reactor at an $\mathrm{OH}$ exposure of $7.8 \times 10^{11}$ molec $\mathrm{cm}^{-3} \mathrm{~s}$ as a function of seed particle concentration using ammonium sulfate and sulfuric acid seeds. Error bars indicate $\pm 1 \sigma$ uncertainty in binned measurements. Lines are power law fits to guide the eye.

and investigate this proposal for isoprene SOA, whereas the effect of sulfate seeds on $\alpha$-pinene SOA yields is minor (Kang et al., 2007).

Figure 5 shows isoprene SOA yields in the flow reactor as a function of $\mathrm{OH}$ exposure using an ammonium sulfate seed particle mass concentration of $20 \mu \mathrm{g} \mathrm{m}^{-3}$, which is comparable to sulfate volume concentrations used by Chhabra et al. (2010). At an OH exposure of $2.9 \times 10^{11} \mathrm{molec} \mathrm{cm}^{-3} \mathrm{~s}$ or less in the flow reactor, the isoprene SOA yield with seeds added to the flow reactor compared to the SOA yield in the Caltech chamber is negligible. As the $\mathrm{OH}$ exposure is increased in the flow reactor, the SOA yield rises to a maximum value of 0.10 at $7.8 \times 10^{11}$ molec $^{-3} \mathrm{~s} \mathrm{OH}$ exposure and then decreases. We note that the same trend was observed without adding seed particles, although with lower SOA yields. The $\mathrm{O} / \mathrm{C}$ ratio of the flow reactor SOA decreases from 0.63 to 0.59 when seeds are added at $7.8 \times 10^{11} \mathrm{molec} \mathrm{cm}^{-3} \mathrm{~s} \mathrm{OH}$ exposure. Figure 5 supports the hypothesis that addition of seed particles promotes condensation, leading to higher SOA yields. Higher concentrations of seed particles may be required for condensation of gas-phase oxidation products to compete with continued $\mathrm{OH}$ oxidation in the gas phase.

To further investigate the effect of seeds on condensation, we measured isoprene SOA yields as a function of ammonium sulfate and sulfuric acid seed particle concentrations (Fig. 6). An OH exposure of $7.8 \times 10^{11} \mathrm{molec} \mathrm{cm}^{-3} \mathrm{~s}$ was used in the flow reactor because this condition provided the best signal-to-noise ratio. It is evident from these figures that adding sulfate seeds significantly increases the SOA yield. At an $\mathrm{OH}$ exposure of $7.8 \times 10^{11} \mathrm{molec}^{-3} \mathrm{~s}$ and a sulfate seed particle concentration of $20 \mu \mathrm{gm}^{-3}$, the yield of isoprene SOA increases from 0.032 to approximately 0.14 in the presence of ammonium sulfate seeds and 0.25 in the presence of sulfuric acid seeds. SMPS size distributions of the mixed particles suggest that most of the particle mass is measured by the AMS (Jayne et. a., 2000). Increasing the seed particle concentration led to a continued increase in the yield, along with a decrease in the $\mathrm{O} / \mathrm{C}$ ratio of the SOA as condensation of less-oxidized products was enhanced. The influence of seed acidity on isoprene SOA yields is well documented (Czoschke, 2003; Surratt et al., 2007; Offenberg et al., 2009), and the magnitude of the SOA yield enhancement in the presence of acidic seeds relative to neutral seeds in our work (factor of 2-3) is similar to these previous studies. Because a systematic isoprene SOA yield enhancement in the presence of neutral seeds (relative to unseeded conditions) is not observed in chamber studies (Chhabra et al., 2010; Brégonzio-Rozier et al., 2015), these measurements suggest seed particles are required in flow reactor measurements of isoprene SOA (and potentially other types of SOA as well) in order to more closely simulate condensation conditions in environmental chambers.

\section{Conclusions}

We performed a systematic intercomparison study of the chemistry and yields of SOA generated from $\mathrm{OH}$ oxidation of a common set of gas-phase precursors in several environmental chambers and a flow reactor. The most significant experimental parameters that varied between chambers and the flow reactor were $\mathrm{OH}$ concentration, residence time, and use of seed particles to promote condensation of oxidized vapors. The $\mathrm{OH}$ concentrations were 100 to 1000 times higher in the flow reactor, and residence times were 100 to 400 times higher in the environmental chambers. Within the range of approximate $\mathrm{OH}$ exposure overlap of (14) $\times 10^{11}$ molec $\mathrm{cm}^{-3} \mathrm{~s}$, the SOA mass spectra and oxidation state were similar in both systems. The SOA yields for representative systems tracked each other but were lower in the flow reactor, probably in part because chamber SOA experiments were done with seed particles to promote condensation of oxidized vapors. Because SOA composition appears to be governed primarily by gas-phase $\mathrm{OH}$ oxidation processes, our results suggest that either flow reactors or chambers are properly characterizing SOA oxidative aging mechanisms representative of ambient conditions. However, SOA yields appear highly sensitive to the relative timescales of gas-phase $\mathrm{OH}$ oxidation and condensation processes. Simple calculations and measurements with seed particles suggest that condensation processes may be residence-time-limited in flow reactors, depending on the mass accommodation coefficient of the oxidized vapors onto pre-existing particles. This could lead to underestimation of SOA yields. However, running an environmental chamber or flow reactor under conditions where partitioning is overestimated relative to atmospheric conditions will lead to a corresponding overestima- 
tion of SOA yields. Environmental chambers are commonly used to constrain SOA yields at low $\mathrm{OH}$ exposures, but flow reactors are needed to constrain SOA yields at higher $\mathrm{OH}$ exposures than 1-2 days of equivalent atmospheric oxidation, because environmental chamber SOA yield measurements appear to significantly underestimate atmospheric SOA formation rates when extrapolated over multiple days of equivalent atmospheric oxidation.

Acknowledgements. This work was supported by the Atmospheric Chemistry Program of the National Science Foundation: grants AGS-1244918 and ATM-0854916 to Boston College; AGS-1244999 and AGS-0904292 to Aerodyne Research, Inc.; AGS-1244995 to Pennsylvania State University; AGS-1056225 and AGS-1245011 to the Massachusetts Institute of Technology and the Office of Science (BER), Department of Energy (Atmospheric Systems Research); and by grants DE-SC0006980, DE-SC0011935, and DE-FG02-05ER63995 to Boston College and Aerodyne Research, Inc. A. T. Lambe acknowledges Paola Massoli, Adam Ahern, David Croasdale, Justin Wright, and Alex Martin for help with previous experimental studies referenced in this paper. P. S. Chhabra acknowledges Xuan Zhang, Christine Loza, and Arthur Chan for help in data analysis of previous chamber studies. We thank the referees and members of Jose Jimenez's research group at the University of Colorado Boulder for their additional comments in the interactive discussion of this paper.

Edited by: H. Grothe

\section{References}

Aiken, A., DeCarlo, P., Kroll, J., Worsnop, D., Huffman, J., Docherty, K., Ulbrich, I., Mohr, C., Kimmel, J., and Sueper, D.: $\mathrm{O} / \mathrm{C}$ and $\mathrm{OM} / \mathrm{OC}$ ratios of primary, secondary, and ambient organic aerosols with high-resolution time-of-flight aerosol mass spectrometry, Environ. Sci. Technol., 42, 4478-4485, 2008.

Atkinson, R.: Kinetics and mechanisms of the gas-phase reactions of the hydroxyl radical with organic compounds under atmospheric conditions, Chem. Rev., 86, 69-201, 1986.

Bahreini, R., Middlebrook, A. M., Brock, C. A., De Gouw, J. A., Mckeen, S. A., Williams, L. R., Daumit, K. E., Lambe, A. T., Massoli, P., Canagaratna, M. R., Ahmadov, R., Carrasquillo, A. J., Cross, E. S., Ervens, B., Holloway, J. S., Hunter, J. F., Onasch, T. B., Pollack, I. B., Roberts, J. M., Ryerson, T. B., Warneke, C., Davidovits, P., Worsnop, D. R., and Kroll, J. H.: Mass spectral analysis of organic aerosol formed downwind of the Deepwater Horizon oil spill: field studies and laboratory confirmations, Environ. Sci. Technol., 46, 8025-8034, 2012.

Bergström, R., Denier van der Gon, H. A. C., Prévôt, A. S. H., Yttri, K. E., and Simpson, D.: Modelling of organic aerosols over Europe (2002-2007) using a volatility basis set (VBS) framework: application of different assumptions regarding the formation of secondary organic aerosol, Atmos. Chem. Phys., 12, 8499-8527, doi:10.5194/acp-12-8499-2012, 2012.
Bernard, F., Fedioun, I., Peyroux, F. Quilgars, A., Daële, V., and Mellouki, A.: Thresholds of secondary organic aerosol formation by ozonolysis of monoterpenes measured in a laminar flow aerosol reactor, J. Aerosol Sci., 43, 14-30, 2012.

Brégonzio-Rozier, L., Siekmann, F., Giorio, C., Pangui, E., Morales, S. B., Temime-Roussel, B., Gratien, A., Michoud, V., Ravier, S., Tapparo, A., Monod, A., and Doussin, J.-F.: Gaseous products and Secondary Organic Aerosol formation during long term oxidation of isoprene and methacrolein, Atmos. Chem. Phys., 15, 2953-2968, doi:10.5194/acp-15-2953-2015, 2015.

Canagaratna, M. R., Jimenez, J. L., Kroll, J. H., Chen, Q., Kessler, S. H., Massoli, P., Hildebrandt Ruiz, L., Fortner, E., Williams, L. R., Wilson, K. R., Surratt, J. D., Donahue, N. M., Jayne, J. T., and Worsnop, D. R.: Elemental ratio measurements of organic compounds using aerosol mass spectrometry: characterization, improved calibration, and implications, Atmos. Chem. Phys., 15, 253-272, doi:10.5194/acp-15-253-2015, 2015.

Cappa, C. D. and Wilson, K. R.: Multi-generation gas-phase oxidation, equilibrium partitioning, and the formation and evolution of secondary organic aerosol, Atmos. Chem. Phys., 12, 9505-9528, doi:10.5194/acp-12-9505-2012, 2012.

Chen, S., Brune, W. H., Lambe, A. T., Davidovits, P., and Onasch, T. B.: Modeling organic aerosol from the oxidation of $\alpha$-pinene in a Potential Aerosol Mass (PAM) chamber, Atmos. Chem. Phys., 13, 5017-5031, doi:10.5194/acp-13-5017-2013, 2013.

Chhabra, P. S., Flagan, R. C., and Seinfeld, J. H.: Elemental analysis of chamber organic aerosol using an aerodyne high-resolution aerosol mass spectrometer, Atmos. Chem. Phys., 10, 4111-4131, doi:10.5194/acp-10-4111-2010, 2010.

Chhabra, P. S., Ng, N. L., Canagaratna, M. R., Corrigan, A. L., Russell, L. M., Worsnop, D. R., Flagan, R. C., and Seinfeld, J. H.: Elemental composition and oxidation of chamber organic aerosol, Atmos. Chem. Phys., 11, 8827-8845, doi:10.5194/acp-11-88272011, 2011.

Czoschke, N.: Effect of acidic seed on biogenic secondary organic aerosol growth, Atmos. Environ., 37, 4287-4299, 2003.

Davis, D. D., Ravishankara, A. R., and Fischer, S.: $\mathrm{SO}_{2}$ oxidation via the hydroxyl radical: atmospheric fate of $\mathrm{HSO}_{\mathrm{X}}$ radicals, Geophys. Res. Lett., 6, 113-116, 1979.

De Gouw, J. A., Middlebrook, A. M., Warneke, C., Ahmadov, R., Atlas, E. L., Bahreini, R., Blake, D. R., Brock, C. A., Brioude, J., Fahey, D. W., Fehsenfeld, F. C., Holloway, J. S., Le Henaff, M., Lueb, R. A., Mckeen, S. A., Meagher, J. F., Murphy, D. M., Paris, C., Parrish, D. D., Perring, A. E., Pollack, I. B., Ravishankara, A. R., Robinson, A. L., Ryerson, T. B., Schwarz, J. P., Spackman, J. R., Srinivasan, A., and Watts, L. A.: Organic aerosol formation downwind from the Deepwater Horizon oil spill, Science, 331, 1295-1299, 2011.

DeCarlo, P. F., Kimmel, J. R., Trimborn, A., Northway, M. J., Jayne, J. T., Aiken, A. C., Gonin, M., Fuhrer, K., Horvath, T., Docherty, K. S., Worsnop, D. R., and Jimenez, J. L.: Fielddeployable, high-resolution, time-of-flight aerosol mass spectrometer, Anal. Chem., 78, 8281-8289, 2006.

Drewnick, F., Hings, S., DeCarlo, P., Jayne, J., Gonin, M., Fuhrer, K., Weimer, S., Jimenez, J., Demerjian, K., Borrmann, S., and Worsnop, D.: A new Time-of-Flight Aerosol Mass Spectrometer (TOF-AMS) - instrument description and first field deployment, Aerosol Sci. Tech., 39, 637-658, 2005. 
Eddingsaas, N. C., Loza, C. L., Yee, L. D., Chan, M., Schilling, K. A., Chhabra, P. S., Seinfeld, J. H., and Wennberg, P. O.: $\alpha$-pinene photooxidation under controlled chemical conditions - Part 2: SOA yield and composition in lowand high- $\mathrm{NO}_{\mathrm{x}}$ environments, Atmos. Chem. Phys., 12, 74137427, doi:10.5194/acp-12-7413-2012, 2012.

Ehn, M., Thornton, J. A., Kleist, E., Sipilä, M., Junninen, H., Pullinen, I., Springer, M., Rubach, F., Tillmann, R., Lee, B., LopezHilfiker, F., Andres, S., Acir, I.-H., Rissanen, M., Jokinen, T., Schobesberger, S., Kangasluoma, J., Kontkanen, J., Nieminen, T., Kurtén, T., Nielsen, L. B., Jørgensen, S., Kjaergaard, H. G., Canagaratna, M., Dal Maso, M., Berndt, T., Petäjä, T., Wahner, A., Kerminen, V.-M., Kulmala, M., Worsnop, D. R., Wildt, J., and Mentel, T. F.: A large source of low-volatility secondary organic aerosol, Nature, 506, 476-479, 2014.

Fountoukis, C., Megaritis, A. G., Skyllakou, K., Charalampidis, P. E., Pilinis, C., Denier van der Gon, H. A. C., Crippa, M., Canonaco, F., Mohr, C., Prévôt, A. S. H., Allan, J. D., Poulain, L., Petäjä, T., Tiitta, P., Carbone, S., Kiendler-Scharr, A., Nemitz, E., O'Dowd, C., Swietlicki, E., and Pandis, S. N.: Organic aerosol concentration and composition over Europe: insights from comparison of regional model predictions with aerosol mass spectrometer factor analysis, Atmos. Chem. Phys., 14, 9061-9076, doi:10.5194/acp-14-9061-2014, 2014

Hall IV, W. A., Pennington, M. R., and Johnston, M. V.: Molecular transformations accompanying the aging of laboratory secondary organic aerosol, Environ. Sci. Technol., 47, 2230-2237, 2013.

Hallquist, M., Wenger, J. C., Baltensperger, U., Rudich, Y., Simpson, D., Claeys, M., Dommen, J., Donahue, N. M., George, C., Goldstein, A. H., Hamilton, J. F., Herrmann, H., Hoffmann, T., Iinuma, Y., Jang, M., Jenkin, M. E., Jimenez, J. L., KiendlerScharr, A., Maenhaut, W., McFiggans, G., Mentel, Th. F., Monod, A., Prévôt, A. S. H., Seinfeld, J. H., Surratt, J. D., Szmigielski, R., and Wildt, J.: The formation, properties and impact of secondary organic aerosol: current and emerging issues, Atmos. Chem. Phys., 9, 5155-5236, doi:10.5194/acp-9-51552009, 2009.

Hamilton, J. F., Rami Alfarra, M., Wyche, K. P., Ward, M. W., Lewis, A. C., McFiggans, G. B., Good, N., Monks, P. S., Carr, T., White, I. R., and Purvis, R. M.: Investigating the use of secondary organic aerosol as seed particles in simulation chamber experiments, Atmos. Chem. Phys., 11, 5917-5929, doi:10.5194/acp11-5917-2011, 2011

Heald, C. L., Kroll, J. H., Jimenez, J. L., Docherty, K. S., DeCarlo, P. F., Aiken, A. C., Chen, Q., Martin, S. T., Farmer, D. K., and Artaxo, P.: A simplified description of the evolution of organic aerosol composition in the atmosphere, Geophys. Res. Lett., 37, L08803, doi:10.1029/2010GL042737, 2010.

Henry, K. and Donahue, N.: Photochemical aging of $\alpha$-pinene secondary organic aerosol: effects of $\mathrm{OH}$ radical sources and photolysis, J. Phys. Chem.-US, 116, 5932-5940, 2012.

Hildebrandt, L., Donahue, N. M., and Pandis, S. N.: High formation of secondary organic aerosol from the photo-oxidation of toluene, Atmos. Chem. Phys., 9, 2973-2986, doi:10.5194/acp-92973-2009, 2009.

Hunter, J. F., Carrasquillo, A. J., Daumit, K. E., and Kroll, J. H.: Secondary organic aerosol formation from acyclic, monocyclic, and polycyclic alkanes, Environ. Sci. Technol., 48, 1022710234, 2014.
Jang, M., Carroll, B., Chandramouli, B., and Kamens, R. M., Particle Growth By Acid-Catalyzed Heterogeneous Reactions of Organic Carbonyls on Preexisting Aerosols, Environ. Sci. Technol., 37, 3828-3837, 2003.

Jayne, J. T., Leard, D. C., Zhang, X., Davidovits, P., Smith, K. A., Kolb, C. E., and Worsnop, D. R.: Development of an Aerosol Mass Spectrometer for Size and Composition Analysis of Submicron Particles, Aerosol Sci. Technol., 33, 49-70, 2000.

Jimenez, J. L., Canagaratna, M. R., Donahue, N. M., Prevot, A. S. H., Zhang, Q., Kroll, J. H., DeCarlo, P. F., Allan, J. D., Coe, H., Ng, N. L., Aiken, A. C., Docherty, K. S., Ulbrich, I. M., Grieshop, A. P., Robinson, A. L., Duplissy, J., Smith, J. D., Wilson, K. R., Lanz, V. A., Hueglin, C., Sun, Y. L., Tian, J., Laaksonen, A., Raatikainen, T., Rautiainen, J., Vaattovaara, P., Ehn, M., Kulmala, M., Tomlinson, J. M., Collins, D. R., Cubison, M. J., Dunlea, J., Huffman, J. A., Onasch, T. B., Alfarra, M. R., Williams, P. I., Bower, K., Kondo, Y., Schneider, J., Drewnick, F., Borrmann, S., Weimer, S., Demerjian, K., Salcedo, D., Cottrell, L., Griffin, R., Takami, A., Miyoshi, T., Hatakeyama, S., Shimono, A., Sun, J. Y., Zhang, Y. M., Dzepina, K., Kimmel, J. R., Sueper, D., Jayne, J. T., Herndon, S. C., Trimborn, A. M., Williams, L. R., Wood, E. C., Middlebrook, A. M., Kolb, C. E., Baltensperger, U., and Worsnop, D. R.: Evolution of organic aerosols in the atmosphere, Science, 326, 1525-1529, 2009.

Jo, D. S., Park, R. J., Kim, M. J., and Spracklen, D. V.: Effects of chemical aging on global secondary organic aerosol using the volatility basis set approach, Atmos. Environ., 81, 230-244, 2013.

Kanakidou, M., Seinfeld, J. H., Pandis, S. N., Barnes, I., Dentener, F. J., Facchini, M. C., Van Dingenen, R., Ervens, B., Nenes, A., Nielsen, C. J., Swietlicki, E., Putaud, J. P., Balkanski, Y., Fuzzi, S., Horth, J., Moortgat, G. K., Winterhalter, R., Myhre, C. E. L., Tsigaridis, K., Vignati, E., Stephanou, E. G., and Wilson, J.: Organic aerosol and global climate modelling: a review, Atmos. Chem. Phys., 5, 1053-1123, doi:10.5194/acp-51053-2005, 2005.

Kang, E., Root, M. J., Toohey, D. W., and Brune, W. H.: Introducing the concept of Potential Aerosol Mass (PAM), Atmos. Chem. Phys., 7, 5727-5744, doi:10.5194/acp-7-5727-2007, 2007.

Kang, E., Toohey, D. W., and Brune, W. H.: Dependence of SOA oxidation on organic aerosol mass concentration and $\mathrm{OH}$ exposure: experimental PAM chamber studies, Atmos. Chem. Phys., 11, 1837-1852, doi:10.5194/acp-11-1837-2011, 2011.

Keller, A. and Burtscher, H.: A continuous photo-oxidation flow reactor for a defined measurement of the SOA formation potential of wood burning emissions, J. Aerosol Sci., 49, 9-20, 2012.

Kroll, J., Ng, N., Murphy, S., Flagan, R., and Seinfeld, J.: Secondary organic aerosol formation from isoprene photooxidation, Environ. Sci. Technol., 40, 1869-1877, 2006.

Kroll, J. H., Donahue, N. M., Jimenez, J. L., Kessler, S. H., Canagaratna, M. R., Wilson, K. R., Altieri, K. E., Mazzoleni, L. R., Wozniak, A. S., Bluhm, H., Mysak, E. R., Smith, J. D., Kolb, C. E., and Worsnop, D. R.: Carbon oxidation state as a metric for describing the chemistry of atmospheric organic aerosol, Nature Chemistry, 3, 133-139, 2011.

Lambe, A. T., Ahern, A. T., Williams, L. R., Slowik, J. G., Wong, J. P. S., Abbatt, J. P. D., Brune, W. H., Ng, N. L., Wright, J. P., Croasdale, D. R., Worsnop, D. R., Davidovits, P., 
and Onasch, T. B.: Characterization of aerosol photooxidation flow reactors: heterogeneous oxidation, secondary organic aerosol formation and cloud condensation nuclei activity measurements, Atmos. Meas. Tech., 4, 445-461, doi:10.5194/amt-4445-2011, 2011a.

Lambe, A. T., Onasch, T. B., Massoli, P., Croasdale, D. R., Wright, J. P., Ahern, A. T., Williams, L. R., Worsnop, D. R., Brune, W. H., and Davidovits, P.: Laboratory studies of the chemical composition and cloud condensation nuclei (CCN) activity of secondary organic aerosol (SOA) and oxidized primary organic aerosol (OPOA), Atmos. Chem. Phys., 11, 8913-8928, doi:10.5194/acp-11-8913-2011, 2011 b.

Lambe, A. T., Onasch, T. B., Croasdale, D. R., Wright, J. P., Martin, A. T., Franklin, J. P., Massoli, P., Kroll, J. H., Canagaratna, M. R., Brune, W. H., Worsnop, D. R., and Davidovits, P.: Transitions from functionalization to fragmentation reactions of laboratory Secondary Organic Aerosol (SOA) generated from the $\mathrm{OH}$ oxidation of alkane precursors, Environ. Sci. Technol., 46, 5430-5437, 2012.

Lambe, A. T., Cappa, C. D., Massoli, P., Onasch, T. B., Forestieri, S. D., Martin, A. T., Cummings, M. J., Croasdale, D. R., Brune, W. H., Worsnop, D. R., and Davidovits, P.: Relationship between oxidation level and optical properties of secondary organic aerosol, Environ. Sci. Technol., 46, 54305437, 2013.

Levin, E. J. T., Prenni, A. J., Palm, B. B., Day, D. A., CampuzanoJost, P., Winkler, P. M., Kreidenweis, S. M., DeMott, P. J., Jimenez, J. L., and Smith, J. N.: Size-resolved aerosol composition and its link to hygroscopicity at a forested site in Colorado, Atmos. Chem. Phys., 14, 2657-2667, doi:10.5194/acp-14-26572014, 2014.

Li, Y. P., Elbern, H., Lu, K. D., Friese, E., Kiendler-Scharr, A., Mentel, Th. F., Wang, X. S., Wahner, A., and Zhang, Y. H.: Updated aerosol module and its application to simulate secondary organic aerosols during IMPACT campaign May 2008, Atmos. Chem. Phys., 13, 6289-6304, doi:10.5194/acp-13-6289-2013, 2013.

Li, R., Palm, B. B., Ortega, A. M., Hlywiak, J., Hu, W., Peng, Z., Day, D. A., Knote, C., Brune, W. H., de Gouw, J. A., Jimenez, J. L.: Modeling the radical chemistry in an Oxidation Flow Reactor: radical formation and recycling, sensitivities, and $\mathrm{OH}$ exposure calibration equation, J. Phys. Chem. A., submitted, 2015.

Loza, C. L., Chhabra, P. S., Yee, L. D., Craven, J. S., Flagan, R. C., and Seinfeld, J. H.: Chemical aging of $m$-xylene secondary organic aerosol: laboratory chamber study, Atmos. Chem. Phys., 12, 151-167, doi:10.5194/acp-12-151-2012, 2012.

Loza, C. L., Craven, J. S., Yee, L. D., Coggon, M. M., Schwantes, R. H., Shiraiwa, M., Zhang, X., Schilling, K. A., Ng, N. L., Canagaratna, M. R., Ziemann, P. J., Flagan, R. C., and Seinfeld, J. H.: Secondary organic aerosol yields of 12-carbon alkanes, Atmos. Chem. Phys., 14, 1423-1439, doi:10.5194/acp14-1423-2014, 2014.

Mao, J., Ren, X., Brune, W. H., Olson, J. R., Crawford, J. H., Fried, A., Huey, L. G., Cohen, R. C., Heikes, B., Singh, H. B., Blake, D. R., Sachse, G. W., Diskin, G. S., Hall, S. R., and Shetter, R. E.: Airborne measurement of $\mathrm{OH}$ reactivity during INTEX-B, Atmos. Chem. Phys., 9, 163-173, doi:10.5194/acp-9163-2009, 2009.
Marcolli., C., Canagaratna, M. R., Worsnop, D. R., Bahreini, R., de Gouw, J. A., Warneke, C., Goldan, P. D., Kuster, W. C., Williams, E. J., Lerner, B. M., Roberts, J. M., Meagher, J. F., Fehsenfeld, F. C., Marchewka, M., Bertman, S. B., and Middlebrook, A. M.: Cluster Analysis of the Organic Peaks in Bulk Mass Spectra Obtained During the 2002 New England Air Quality Study with an Aerodyne Aerosol Mass Spectrometer, Atmos. Chem. Phys., 6, 5649-5666, doi:10.5194/acp-6-5649-2006, 2006.

Massoli, P., Lambe, A. T., Ahern, A. T., Williams, L. R., Ehn, M., Mikkilä, J., Canagaratna, M. R., Brune, W. H., Onasch, T. B., Jayne, J. T., Petäjä, T., Kulmala, M., Laaksonen, A., Kolb, C. E., Davidovits, P., and Worsnop, D. R.: Relationship between aerosol oxidation level and hygroscopic properties of laboratory generated secondary organic aerosol (SOA) particles, Geophys. Res. Lett., 37, L24801, doi:10.1029/2010GL045258, 2010.

Matsunaga, A. and Ziemann, P.: Gas-wall partitioning of organic compounds in a teflon film chamber and potential effects on reaction product and aerosol yield measurements, Aerosol Sci. Tech., 44, 881-892, 2010.

Mei, F., Setyan, A., Zhang, Q., and Wang, J.: CCN activity of organic aerosols observed downwind of urban emissions during CARES, Atmos. Chem. Phys., 13, 12155-12169, doi:10.5194/acp-13-12155-2013, 2013.

Moore, R., Raatikainen, T., Langridge, J., Bahreini, R., Brock, C., Holloway, J., Lack, D., Middlebrook, A., Perring, A., Schwarz, J., Spackman, J., and Nenes, A.: CCN spectra, hygroscopicity, and droplet activation kinetics of secondary organic aerosol resulting from the 2010 Deepwater Horizon oil spill, Environ. Sci. Technol., 46, 3093-3100, 2012.

Murphy, D. M., Middlebrook, A. M., and Warshawsky, M.: Cluster Analysis of Data from the Particle Analysis by Laser Mass Spectrometry (PALMS) Instrument, Aerosol Sci. Tech., 37, 382-391, 2003.

Ng, N. L., Chhabra, P. S., Chan, A. W. H., Surratt, J. D., Kroll, J. H., Kwan, A. J., McCabe, D. C., Wennberg, P. O., Sorooshian, A., Murphy, S. M., Dalleska, N. F., Flagan, R. C., and Seinfeld, J. H.: Effect of $\mathrm{NO}_{\mathrm{x}}$ level on secondary organic aerosol (SOA) formation from the photooxidation of terpenes, Atmos. Chem. Phys., 7, 5159-5174, doi:10.5194/acp-7-5159-2007, 2007.

Ng, N. L., Canagaratna, M. R., Zhang, Q., Jimenez, J. L., Tian, J., Ulbrich, I. M., Kroll, J. H., Docherty, K. S., Chhabra, P. S., Bahreini, R., Murphy, S. M., Seinfeld, J. H., Hildebrandt, L., Donahue, N. M., DeCarlo, P. F., Lanz, V. A., Prévôt, A. S. H., Dinar, E., Rudich, Y., and Worsnop, D. R.: Organic aerosol components observed in Northern Hemispheric datasets from Aerosol Mass Spectrometry, Atmos. Chem. Phys., 10, 46254641, doi:10.5194/acp-10-4625-2010, 2010.

Offenberg, J., Lewandowski, M., Edney, E., Kleindienst, T., and Jaoui, M.: Influence of aerosol acidity on the formation of secondary organic aerosol from biogenic precursor hydrocarbons, Environ. Sci. Technol., 43, 7742-7747, 2009.

Ofner, J., Krüger, H.-U., and Zetzsch, C.: Time Resolved Infrared Spectroscopy of Formation and Processing of Secondary Organic Aerosol, Z. Phys. Chem., 224, 1171-1183, 2010.

Ortega, A. M., Day, D. A., Cubison, M. J., Brune, W. H., Bon, D., de Gouw, J. A., and Jimenez, J. L.: Secondary organic aerosol formation and primary organic aerosol oxidation from biomass-burning smoke in a flow reactor during FLAME- 
3, Atmos. Chem. Phys., 13, 11551-11571, doi:10.5194/acp-1311551-2013, 2013.

Pfaffenberger, L., Barmet, P., Slowik, J. G., Praplan, A. P., Dommen, J., Prévôt, A. S. H., and Baltensperger, U.: The link between organic aerosol mass loading and degree of oxygenation: an $\alpha$ pinene photooxidation study, Atmos. Chem. Phys., 13, 64936506, doi:10.5194/acp-13-6493-2013, 2013.

Pierce, J. R., Engelhart, G. J., Hildebrandt, L., Weitkamp, E. A., Pathak, R. K., Donahue, N. M., Robinson, A. L., Adams, P. J., and Pandis, S. N.: Constraining particle evolution from wall losses, coagulation, and condensation-evaporation in smogchamber experiments: optimal estimation based on size distribution measurements, Aerosol Sci. Tech., 42, 1001-1015, 2008.

Presto, A. and Donahue, N.: Investigation of $\alpha$-pinene+ ozone secondary organic aerosol formation at low total aerosol mass, Environ. Sci. Technol., 40, 3536-3543, 2006.

Presto, A., Hartz, K., and Donahue, N.: Secondary organic aerosol production from terpene ozonolysis. 2. Effect of $\mathrm{NO}_{\mathrm{x}}$ concentration, Environ. Sci. Technol., 39, 7046-7054, 2005.

Renbaum, L. H. and Smith, G. D.: Artifacts in measuring aerosol uptake kinetics: the roles of time, concentration and adsorption, Atmos. Chem. Phys., 11, 6881-6893, doi:10.5194/acp-11-68812011, 2011.

Saleh, R., Donahue, N. M., and Robinson, A. L.: Time scales for gas-particle partitioning equilibration of secondary organic aerosol formed from $\alpha$-pinene ozonolysis, Environ. Sci. Technol., 47, 5588-5594, 2013.

Seinfeld, J. H., and Pandis, S. N.: Atmospheric Chemistry and Physics: From Air Pollution to Climate Change, 2 Edn., J. Wiley, New York, 2006.

Shrivastava, M., Fast, J., Easter, R., Gustafson Jr., W. I., Zaveri, R. A., Jimenez, J. L., Saide, P., and Hodzic, A.: Modeling organic aerosols in a megacity: comparison of simple and complex representations of the volatility basis set approach, Atmos. Chem. Phys., 11, 6639-6662, doi:10.5194/acp-11-66392011, 2011.

Sihto, S.-L., Mikkilä, J., Vanhanen, J., Ehn, M., Liao, L., Lehtipalo, K., Aalto, P. P., Duplissy, J., Petäjä, T., Kerminen, V.M., Boy, M., and Kulmala, M.: Seasonal variation of CCN concentrations and aerosol activation properties in boreal forest, Atmos. Chem. Phys., 11, 13269-13285, doi:10.5194/acp-1113269-2011, 2011.

Slowik, J. G., Wong, J. P. S., and Abbatt, J. P. D.: Real-time, controlled $\mathrm{OH}$-initiated oxidation of biogenic secondary organic aerosol, Atmos. Chem. Phys., 12, 9775-9790, doi:10.5194/acp12-9775-2012, 2012.

Spracklen, D. V., Jimenez, J. L., Carslaw, K. S., Worsnop, D. R., Evans, M. J., Mann, G. W., Zhang, Q., Canagaratna, M. R., Allan, J., Coe, H., McFiggans, G., Rap, A., and Forster, P.: Aerosol mass spectrometer constraint on the global secondary organic aerosol budget, Atmos. Chem. Phys., 11, 12109-12136, doi:10.5194/acp-11-12109-2011, 2011.

Surratt, J. D., Lewandowski, M., Offenberg, J. H., Jaoui, M., Kleindienst, T. E., Edney, E. O., and Seinfeld, J. H.: Effect of acidity on secondary organic aerosol formation from isoprene, Environ. Sci. Technol., 41, 5363-5369, 2007.
Tkacik, D. S., Presto, A. A., Donahue, N. M., and Robinson, A. L.: Secondary organic aerosol formation from intermediate-volatility organic compounds: cyclic, linear, and branched alkanes, Environ. Sci. Technol., 46, 8773-8781, 2012.

Tkacik, D. S., Lambe, A. T., Jathar, S.,Li, X.,Presto, A. A., Zhao, Y., Blake, D. R., Meinardi, S., Jayne, J. T., Croteau, P. L., and Robinson, A. L.: Secondary organic aerosol formation from in-use motor vehicle emissions using a Potential Aerosol Mass reactor, Environ. Sci. Technol., 48, 11235-11242, 2014.

Volkamer, R., Ziemann, P. J., and Molina, M. J.: Secondary Organic Aerosol Formation from Acetylene $\left(\mathrm{C}_{2} \mathrm{H}_{2}\right)$ : seed effect on SOA yields due to organic photochemistry in the aerosol aqueous phase, Atmos. Chem. Phys., 9, 1907-1928, doi:10.5194/acp9-1907-2009, 2009.

Wang, B., Lambe, A., Massoli, P., Onasch, T. B., Davidovits, P., Worsnop, D. R., and Knopf, D. A.: The deposition ice nucleation and immersion freezing potential of amorphous secondary organic aerosol: pathways for ice and mixed-phase cloud formation, J. Geophys. Res., 117, D16209, doi:10.1029/2012JD018063, 2012.

Wong, J. P. S., Lee, A. K. Y., Slowik, J. G., Cziczo, D. J., Leaitch, W. R., Macdonald, A., and Abbatt, J. P. D.: Oxidation of ambient biogenic secondary organic aerosol by hydroxyl radicals: effects on cloud condensation nuclei activity, Geophys. Res. Lett., 38, L22805, doi:10.1029/2011GL049351, 2011.

Zhang, Q., Alfarra, M., Worsnop, D., Allan, J., Coe, H., Canagaratna, M., and Jimenez, J.: Deconvolution and quantification of hydrocarbon-like and oxygenated organic aerosols based on aerosol mass spectrometry, Environ. Sci. Technol., 39, 49384952, 2005.

Zhang, Q., Jimenez, J. L., Canagaratna, M. R., Allan, J. D., Coe, H., Ulbrich, I., Alfarra, M. R., Takami, A., Middlebrook, A. M., Sun, Y. L., Dzepina, K., Dunlea, E., Docherty, K., DeCarlo, P. F., Salcedo, D., Onasch, T., Jayne, J. T., Miyoshi, T., Shimono, A., Hatakeyama, S., Takegawa, N., Kondo, Y., Schneider, J., Drewnick, F., Borrmann, S., Weimer, S., Demerjian, K., Williams, P., Bower, K., Bahreini, R., Cottrell, L., Griffin, R. J., Rautiainen, J., Sun, J. Y., Zhang, Y. M., and Worsnop, D. R.: Ubiquity and dominance of oxygenated species in organic aerosols in anthropogenically-influenced Northern Hemisphere midlatitudes, Geophys. Res. Lett., 34, L13801, doi:10.1029/2007GL029979, 2007.

Zhang, X., Lin, Y.-H., Surratt, J. D., Zotter, P, Prévôt, A. S. H., and Weber, R. J.: Light-absorbing soluble organic aerosol in Los Angeles and Atlanta: a contrast in secondary organic aerosol, Geophys. Res. Lett., 38, L21810, doi:10.1029/2011GL049385, 2011.

Zhang, X., Cappa, C. D., Jathar, S. H., McVay, R. C., Ensberg, J. J., Kleeman, M. J., and Seinfeld, J. H.: Influence of vapor wall loss in laboratory chambers on yields of secondary organic aerosol, $\mathrm{P}$. Natl. Acad. Sci. USA, 111, 5802-5807, 2014. 